\title{
Effects of Leonardite and Mineral Fertilizer Applications on Plant Growth and Soil Quality of Garlic (Allium sativum L.)
}

\begin{abstract}
Temel Sarıyıldız $\mathbf{1}^{1, \mathrm{a}, *}$
${ }^{1}$ Soil Science and Ecology Branch, Department of Forest Engineering, Faculty of Forestry, Bursa Technical University, 16310 Bursa, Turkey *Corresponding author

A R T I C L E I N F A B S T R A C T

Research Article

Turkey is one of the major garlic producing country in the world and the significant amount of Turkey's production has been made using a garlic variety called Taşköprü garlic (Allium sativum L.) in Kastamonu, Turkey. In order to improve the quality of garlic production, a field experiment was conducted to evaluate the effects of different doses of leonardite organic fertilizer, mineral fertilizer NPK and the mixture of both the leonardite and NPK fertilizers on the soil properties and mean performances of different characters and yield production of Taşköprü garlic. The treatments were: the plots without leonardite and NPK fertilizers (Control), (2) $80 \mathrm{~N} \mathrm{~kg} \mathrm{ha}^{-1}+40 \mathrm{~kg} \mathrm{ha}^{-1} \mathrm{P}_{2} \mathrm{O}_{5}+100$ $\mathrm{kg} \mathrm{ha}^{-1} \mathrm{~K}_{2} \mathrm{O}(\mathrm{MF})$, (3) 2.6 ton ha-1 leonardite (Leo1), (4) 6.9 ton ha-1 leonardite (Leo2), (5) 9.7 ton $\mathrm{ha}^{-1}$ leonardite (Leo3), (6) Leo1 $+\mathrm{MF}$, (7) Leo $2+\mathrm{MF}$ and Leo3 + MF. Most soil characteristics and the different characters and yield production of Taşköprü garlic statistically varied between the

Keywords:

Allium sativum

Leonardite

Inorganic fertilizer

Soil organic carbon

Nutrients

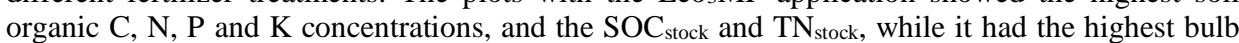
weight, length, equatorial diameter, weight of cloves, width of cloves, length of cloves as well as bulb yield per decare. Of the soil properties, the garlic yield was strongly positively correlated with the soil $\mathrm{N}$ concentration, indicating that the applications of leonardite with the different doses or the mixture of leonardite with the mineral fertilizer were resulting in higher soil $\mathrm{N}$ concentration and thus having the greatest effect on the garlic yields.
\end{abstract}

\section{Introduction}

Garlic (Allium sativum L.) is one of the most important bulb vegetable crops and it is commonly used in the world as a spice or in medicine for a wide range of symptoms such as asthma, hypertension, bronchitis, cancer, circulatory weaknesses, colds, colitis, and coughing (Kaul, 1997). Garlic is also an important crop in Turkey and it has generally been cultivated for both domestic consumption and export. Turkey has 11.916 ha. garlic planting area and it is the fourteenth on the list in the world with 143.207 tonnes of production (FAO, 2018). Garlic is produced in almost all regions in Turkey, with exception of the northeast Turkey. Among all the regions, Kastamonu Province in the northwest Turkey has the highest production area, especially in Taşköprü town (nearly $26 \%$ of total production) with a Geographical Indication as "Taşköprü Garlic" in the region (Ibret, 2005). The cultivation area has continued to increase year by year in the Kastamonu Province. In 2012, the cultivated area of garlic in Taşköprü was 18.500 ha. with total production of
16,650 tons, while in 2016 this number increased to 2055 ha. with total production of 24024 tons (Çobanoğlu et al., 2016; Bayraklı and Gül, 2018). However, growing garlic in the newly reclaimed soils is, however, faced by various problems such as low amounts of available nutrients and poor organic matter content in the soil as well as poor hydrophobic, chemical and biological properties (Shafeek et al., 2015). Like other crops, the garlic plants also require appropriate proportions of nutrients and suitable environment. Although Taşköprü has an optimum climate for garlic production with a warm, humid spring (Anonymous, 2012), a number of studies on the productivity and nutrient content of the Taşköprü garlic have shown that the soils on which the Taşköprü garlic grows show nutrient deficiencies: nitrogen (67.5\%), phosphorus (40\%), Sulphur (82.5\%), potassium (5\%), zinc and manganese $(97.5 \%)$, iron $(7.5 \%)$ and organic matter (55\%) (Taban et al., 2004; Akça et al., 2017). As emphasized by many authors (Henao and Baanante, 1999; 
Tan et al., 2005), the rapid population growth and high demand for agricultural products generally result in using agricultural field intensely and finally it causes the reduction of organic matter and nutrients in soils, and so the reduction of the productivity and sustainability skills of agricultural land, which were productive before.

In order to increase the reduction in productivity of agricultural lands and to get a higher yield per unit area, one of the most common methods is to regain the lack of plant nutrients back into the soil with fertilizers. The most common way is to use some inorganic fertilizers. However, the use of inorganic fertilizers alone may cause problems for human health and the environment (Kumar et al., 2019). In order to reduce the negative effects of inorganic fertilizer, addition of organic fertilizers either alone or in addition to inorganic fertilizers has been increasing in the soil to regain the lost properties (Chen, 2006). One of these organic fertilizers is leonardite which is named in other countries as humat, organic humat, humalit or humus
(Akinremi et al., 2000). Leonardite consists of 30 to $80 \%$ humic acids and thus could be used as a soil amendment (Schnitzer, 1992; Akinremi et al., 2000; Erkoc, 2009; Sugier et al., 2013) Many studies have reported that application of humic substances can improve plant growth and increase crop production (Paksoy et al., 2010; Aisha et al., 2014; Shafeek et al., 2015). However, the effects of leonardite on soil properties and plant growth have received less attention (Ece et al., 2007; Halil et al., 2011; Sanli et al., 2013) and in our knowledge there is no information available about the interactions of both ground leonardite and the mineral fertilizers effects as soil amendments on plant growth, production and soil properties of garlic (Allium sativum L.) plantations. Therefore, this study aimed at determining the effects of different doses of leonardite either alone or in addition to inorganic NPK fertilizers on morphology, yield, nutrient content and soil quality of the Taşköprü garlic.

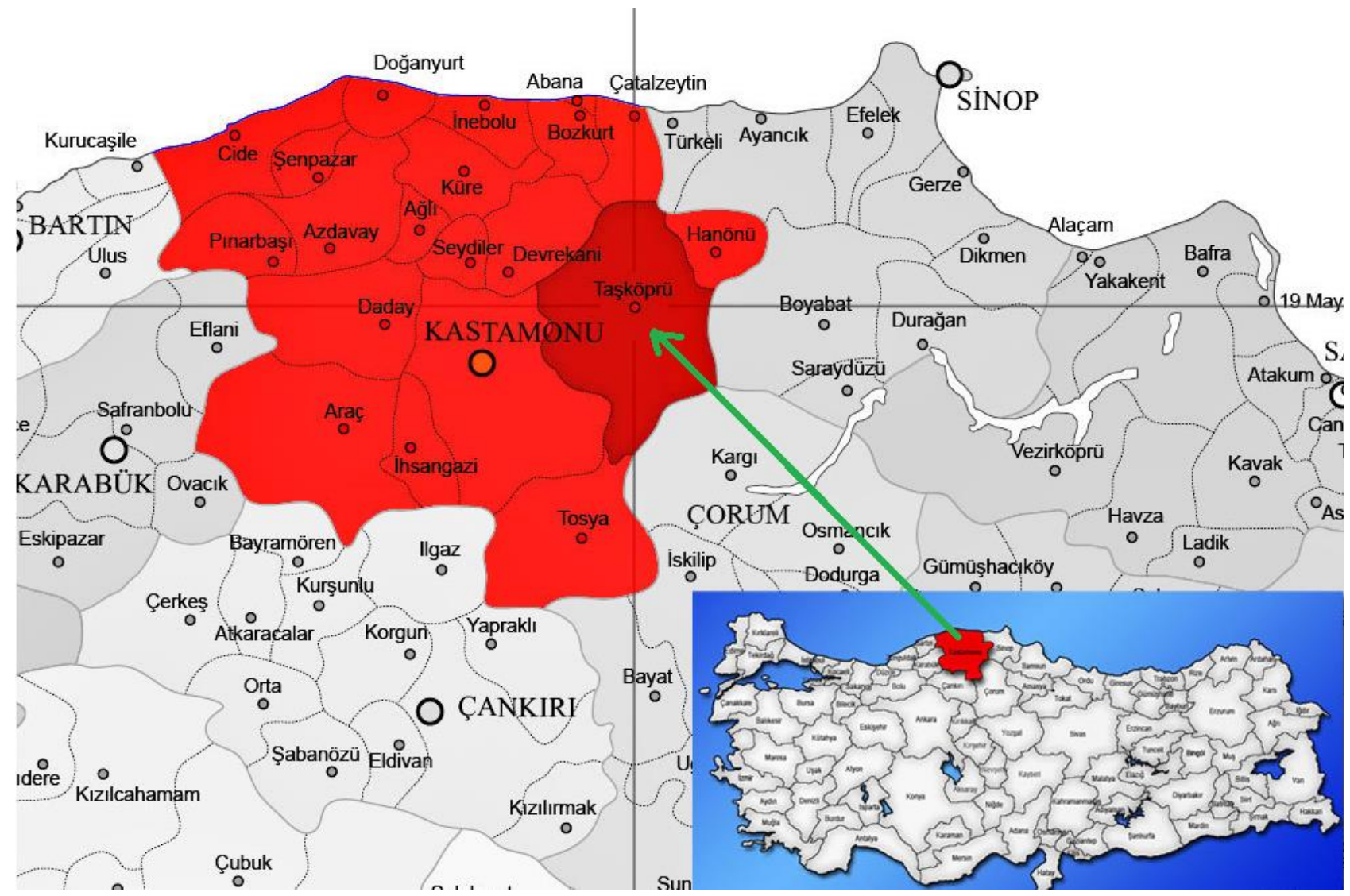

Figure 1. Location of the study area in Kastamonu, Turkey

Table 1. Treatments carried out on Taşköprü garlic (Allium sativum L.)

\begin{tabular}{|c|c|c|c|c|}
\hline Treatment & $\begin{array}{c}\text { Leonardite } \\
\left(\text { ton } \mathrm{ha}^{-1}\right)\end{array}$ & $\begin{array}{c}\mathrm{N} \\
\left(\mathrm{kg} \mathrm{ha}^{-1}\right)\end{array}$ & $\begin{array}{c}\mathrm{K}_{2} \mathrm{O} \\
\left(\mathrm{kg} \mathrm{ha}^{-1}\right)\end{array}$ & $\begin{array}{c}\mathrm{P}_{2} \mathrm{O}_{5} \\
\left.\mathrm{~kg} \mathrm{ha}^{-1}\right)\end{array}$ \\
\hline Control & 0 & 0 & 0 & 0 \\
\hline mineral Fertilizer (MF) & 0 & 80 & 100 & 40 \\
\hline $\mathrm{Leo}_{1}$ & 2.8 & 0 & 0 & 0 \\
\hline $\mathrm{LeO}_{2}$ & 6.9 & 0 & 0 & 0 \\
\hline $\mathrm{LeO}_{3}$ & 9.7 & 0 & 0 & 0 \\
\hline $\mathrm{Leo}_{1} \mathrm{MF}$ & 2.8 & 80 & 100 & 40 \\
\hline $\mathrm{Leo}_{1} \mathrm{MF}$ & 6.9 & 80 & 100 & 40 \\
\hline $\mathrm{Leo}_{1} \mathrm{MF}$ & 9.7 & 80 & 100 & 40 \\
\hline
\end{tabular}




\section{Materials and Methods}

\section{Description of Study Site and Experimental Design}

This study was carried out in Taşköprü, Kastamonu province, the northwest Turkey (41 $30^{\circ} 35^{\prime \prime} \mathrm{N}$ and $34^{\circ} 12^{\prime}$ $37 "$ E) (Figure 1). Mean annual precipitation in Taşköprü is $652 \mathrm{~mm}$, with the highest amounts in December (72 $\mathrm{mm})$, and the lowest amount in July ( $35 \mathrm{~mm})$. Mean annual temperature is $11.7^{\circ} \mathrm{C}$, and average monthly temperature ranges from $20.8^{\circ} \mathrm{C}$ in July to $2.3^{\circ} \mathrm{C}$ in January.

The crop in this study was Allium sativum L., a species in the onion genus, Allium, commonly known in Turkey as Taşköprü garlic. The experimental design was a randomized split plot design with three replicates. The size of plot was $2.88 \mathrm{~m}^{2}(1.6 \times 1.8 \mathrm{~m})$ and interrow spacing was $1 \mathrm{~m}$. Plant (Taşköprü garlic) distances within the rows were $50 \mathrm{~cm}$. The factors studied were ground leonardite and mineral fertilizer rates (NPK). Leonardite was ground and passed through a $2 \mathrm{~mm}$ mesh sieve and was applied at the rates of 2.8, 6.9 and 9.7 ton $\mathrm{ha}^{-1}$ to the plots. The amounts of phosphate $\left(\mathrm{P}_{2} \mathrm{O}_{5}\right)$, potash $\left(\mathrm{K}_{2} \mathrm{O}\right)$ and urea used in the present study were based on the standard recommendation for the Taşköprü garlic in Kastamonu. The factors of experiment consisted of 8 treatments (Table 1). The application rates were (1) the plots without leonardite and NPK fertilizers (Control), (2) $80 \mathrm{~N} \mathrm{~kg} \mathrm{ha-1} \mathrm{+} 40 \mathrm{~kg} \mathrm{ha}^{-1}$ $\mathrm{P}_{2} \mathrm{O}_{5}+100 \mathrm{~kg} \mathrm{ha}^{-1} \mathrm{~K}_{2} \mathrm{O}(\mathrm{MF})$, (3) 2.6 tones ha ${ }^{-1}$ leonardite $\left(\mathrm{Leo}_{1}\right),(4) 6.9$ tones ha- ${ }^{-1}$ leonardite $\left(\mathrm{Leo}_{2}\right),(5) 9.7$ tones ha ${ }^{1}$ leonardite $\left(\mathrm{Leo}_{3}\right),(6) \mathrm{Leo}_{1}+\mathrm{MF},(7) \mathrm{Leo}_{2}+\mathrm{MF}$ and $\mathrm{Leo}_{3}$ + MF. Total plots were 48 (3 replicates $\times 8$ treatments $\times 2$ study sites $=48$ plots) (Figure $2 \mathrm{a}$ ). The research area was irrigated twice with 7 days intervals.

Different doses of the leonardite, the mineral fertilizer and the combinations of both were applied and mixed before sowing (ure $2 b$ ). The Taşköprü garlics were sown on the plots in March (ure 2c). The sown garlics started merging from the last week of June (ure 2d). The garlic plants were watered during the growing season (ure 2e). The garlic plants were harvested in August (ure 2f). Observations were recorded on 10 randomly selected plants from each plot (ure $2 \mathrm{~g}$ ) for yield parameters, weight of bulb ( $\mathrm{g})$, length of bulb (mm), equatorial diameter of bulb (mm), number of cloves per bulb, weight of cloves $(\mathrm{g})$, width of cloves $(\mathrm{mm})$, length of cloves $(\mathrm{g})$, bulb yield (g per plot) and bulb yield $\left(\mathrm{kg} \mathrm{da}^{-1}\right)$ after harvesting. Mean concentrations of nitrogen, phosphorus and potassium in garlic leaves were also determined from each plot.

\section{Soil Sampling and Analysis}

Prior to the commencement of the field experiment, mineral soil samples were taken from the depth of $20 \mathrm{~cm}$ using a soil core (diameter $5 \mathrm{~cm}$ ). Bulk density was determined by weight loss after drying the undisturbed soil core. The soil samples were air-dried, crushed, and passed through a 2-mm sieve prior to analysis. The soil samples were then analysed for $\mathrm{pH}$, soil texture, water holding capacity, soil organic matter, Kjeldahl-N, K and P. A glass calomel electrode was used to measure the soil $\mathrm{pH}$ in deionized $\mathrm{H}_{2} \mathrm{O}$. The soil texture was determined by the hydrometer method (Gülçur 1974). Percent soil organic matter was found using the wet digestion method (Kalra and Maynard, 1991). A factor of 0.58 was then used to convert soil organic matter to soil organic carbon. Concentration of
$\mathrm{K}$ was determined by flame emission spectrophotometer (FES) and $\mathrm{P}$ by continuous flow colorimetry using the molybdenum blue method (Allen, 1989). Standard procedures were also used to determine the selected chemical properties of leonardite. All analyses were carried out in triplicate.

After the harvest, mineral soils from the depth of 0-20 $\mathrm{cm}$ soil depth were also sampled and analysed for $\mathrm{pH}$, texture, water holding capacity, organic matter, Kjeldahl-N, $\mathrm{K}$ and $\mathrm{P}$ as previously outlined.

Total soil organic carbon (SOC) and total nitrogen (TN) stocks were calculated as $\mathrm{Mg} \mathrm{ha}^{-1}$ by the following formula (Lee et al., 2009).

$\mathrm{SOC}_{\text {stock }}$ or $\mathrm{TN}_{\text {stock }}=\mathrm{SOC}$ or $\mathrm{TN} \times \mathrm{BDi} \times \mathrm{H} \times 10^{4}$

Where;

SOC or TN =Is the quantity of the soil organic carbon,

$\mathrm{BDi}=$ Is the bulk density $\left(\mathrm{Mg} \mathrm{m}^{-3}\right)$

$\mathrm{H} \quad=$ Is the depth (m) of respective soil layers

$10^{4}=$ Is a unit conversion factor.

\section{Statistical Analysis}

The data were analysed statistically by analysis of variance to detect the treatment effects. Means of the treatments was compared using Duncan's Multiple Range Test DMRT). All statistical analyses were conducted using IBM SPSS Statistics 20 for Windows (SPSS Inc, Chicago, IL, USA).

\section{Results}

\section{Soil Characteristics of Experimental Plots Before and After Harvesting}

The selected soil physico-chemical properties of the experimental plots and the leonardite before sowing are presented in Table 2. Regardless of the treatment, soil $\mathrm{pH}$, soil texture, N, K and $\mathrm{P}$ were typical of Taşköprü soil (Taban et al., 2004). The soils in the experimental plots were slightly basic (7.60), with low organic carbon $(1.09 \%)$ and sandy loam texture (Table 2). Mean nitrogen (\%), phosphorus $\left(\mathrm{mg} \mathrm{kg}^{-1}\right)$ and potassium $\left(\mathrm{mg} \mathrm{kg}^{-1}\right)$ concentrations $\left(\mathrm{mg} \mathrm{kg}^{-1}\right)$ were $0.108,7.4$ and 82 respectively. Mean soil moisture was $50 \%$.

The $\mathrm{pH}$ (water), organic matter (OM) (\%), N (\%), P (\%) and $\mathrm{K}(\%)$ contents of leonardite were $6.70,50.2,1.12 \%$ 0.09 and 0.51 respectively and they were consistent with those reported in the literature (Yolcu, 2011).

At the end of the experiments after harvesting, the soil properties from the control, the leonardite $\left(\mathrm{Leo}_{1}, \mathrm{LeO}_{2}\right.$ and $\mathrm{Leo}_{3}$ ), the mineral fertilizer (MF) and the leonardite plus mineral fertilizer application plots $\left(\mathrm{Leo}_{1} \mathrm{MF}, \mathrm{Leo}_{2} \mathrm{MF}\right.$ and $\mathrm{Leo}_{3} \mathrm{MF}$ ) are presented in Table 3 . All soil characteristics statistically showed a significant variation with the treatments $(\mathrm{P}<0.001)$. Compared to the control plots, soil $\mathrm{pH}$ showed a decrease with the fertilizer applications, while soil organic carbon (SOC), total nitrogen (TN), soil moisture, $\mathrm{P}$ and $\mathrm{K}$ had an increase (Table 3 ). In general, the soil sand and clay contents tended to increase with the fertilizer applications, whereas the silt content tended to decrease with the fertilizer applications. 


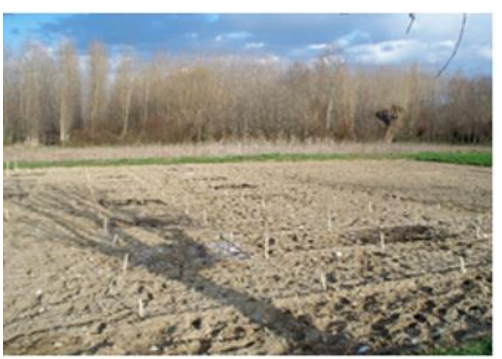

(a)

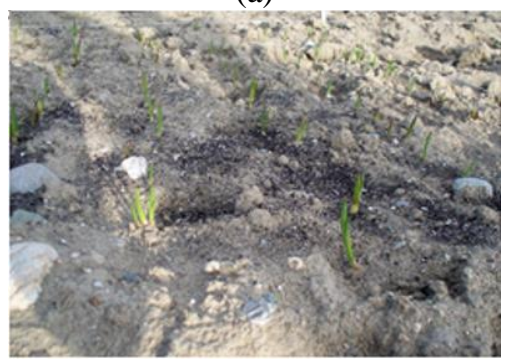

(d)

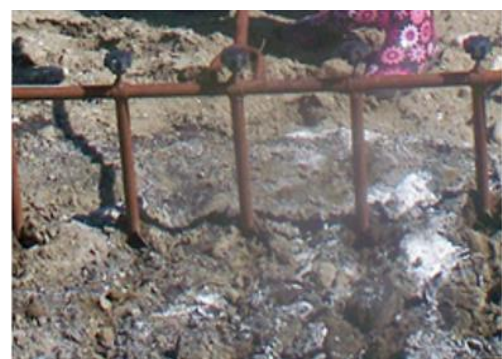

(b)

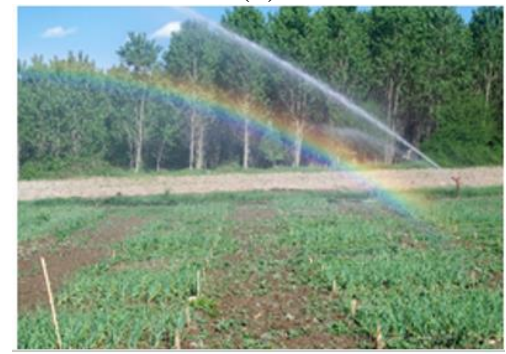

(e)

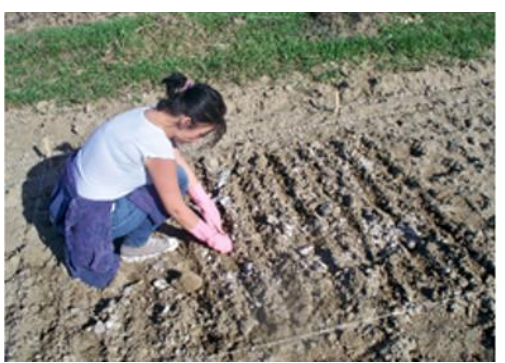

(c)

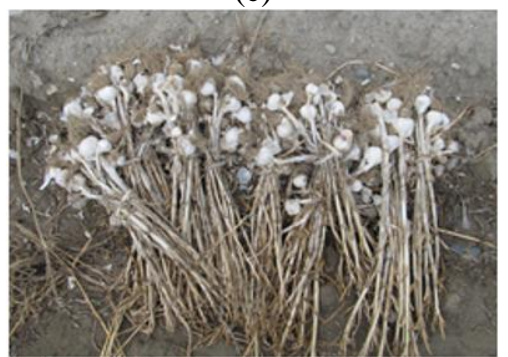

(f)

Figure 2. The experimental was carried out in the field, (a) the experimental plots, (b) mixing the fertilizers in the plots,

(c) sowing the garlics in the plots, (d) emerging garlic plants, (e) watering the plots, (f) harvesting garlic plants

As seen in Table 3 , the addition of leonardite + mineral fertilizers to the soil nearly reduced the soil $\mathrm{pH} 1.6$ unit. The plots with higher doses $\left(9.7\right.$ tones $\left.\mathrm{ha}^{-1}\right) \mathrm{Leo}_{3} \mathrm{MF}$ application had the highest soil organic carbon and nitrogen $(3.10 \%$ and $0.78 \%$ respectively) compared to the control which had the lowest contents $(1.17 \%$ and $0.23 \%$ respectively). The application of only mineral fertilizers or the different dose leonardites increased the SOC nearly 2-fold and 2.5-fold respectively, while the applications of both mineral fertilizers and the different leonardite doses increased the SOC 3-fold. On the other hand, the application of only mineral fertilizers did not significantly vary soil $\mathrm{N}$ content, while the different dose leonardites increased the soil N 2.5-fold. However, the applications of both mineral fertilizers and the different leonardite doses increased the soil N 3.5-fold.

The application of only mineral fertilizers did not significantly vary the $\mathrm{SOC}_{\text {stock }}$ and $\mathrm{TN}_{\text {stock }}$ (Table 3 ) in the soils, however, the applications of the different leonardite doses or the mixture of different leonardite doses and the mineral fertilizers significantly varied the $\mathrm{SOC}_{\text {stock }}$ and $\mathrm{TN}_{\text {stock}}$. The $\mathrm{SOC}_{\text {stock }}$ and $\mathrm{TN}_{\text {stock }}$ from the plots with $\mathrm{Leo}_{3} \mathrm{MF}$ application were highest $\left(78.8 \mathrm{Mg} \mathrm{ha}^{-1}\right.$ and $19.9 \mathrm{Mg} \mathrm{ha}^{-1}$ respectively), compared to the control plots $\left(29.6 \mathrm{Mg} \mathrm{ha}^{-1}\right.$ and $5.8 \mathrm{Mg} \mathrm{ha}^{-1}$ respectively). The application of different dose leonardites increased the $\mathrm{SOC}_{\text {stock }}$ and $\mathrm{TN}_{\text {stock }}$ nearly 2 -fold and 2.4-fold respectively, while the applications of both mineral fertilizers and the different leonardite doses increased the $\mathrm{SOC}_{\text {stock }}$ and $\mathrm{TN}_{\text {stock }} 2.7$-fold and 3.5-fold.

Similar to the SOC and TN contents, $\mathrm{P}$ and $\mathrm{K}$ concentrations were also highest in the soil from the $\mathrm{Leo}_{3} \mathrm{MF}$ application plots (14.9 $\mathrm{mg} \mathrm{kg}^{-1}$ and $286 \mathrm{mg} \mathrm{kg}^{-1}$ respectively), and the lowest for the control plots $\left(9.3 \mathrm{mg} \mathrm{kg}^{-1}\right.$ and $107 \mathrm{mg}$ $\mathrm{kg}^{-1}$ respectively). The application of only mineral fertilizers did not significantly vary $\mathrm{P}$ concentration, while the different dose leonardites increased the $\mathrm{P}$ concentration 1.3-fold. However, the applications of both mineral fertilizers and the different leonardite doses increased the $\mathrm{P}$ concentration 1.6 fold. The $\mathrm{K}$ concentration increased 1.25 fold with the application of mineral fertilizers, 2.12 fold with the different leonardite doses, and 2.67 fold with the applications of both mineral fertilizers and the different leonardite doses.
Table 2. Selected physical and chemical properties of experimental site and leonardite before sowing

\begin{tabular}{l|c}
\hline \multicolumn{1}{c}{ Soil physico-chemical properties } & Values \\
\hline $\mathrm{pH}\left(\mathrm{H}_{2} \mathrm{O}\right)$ & 7.60 \\
Soil Organic Carbon (\%) & 1.09 \\
$\mathrm{~N}(\%)$ & 0.108 \\
$\mathrm{P}\left(\mathrm{mg} \mathrm{kg}^{-1}\right)$ & 7.4 \\
$\mathrm{~K}\left(\mathrm{mg} \mathrm{kg}^{-1}\right)$ & 82 \\
Sand (\%) & 75 \\
Silt (\%) & 8 \\
Clay (\%) & 17 \\
Soil moisture (\%) & 50 \\
Fertilizer (Leonardite) & \\
$\mathrm{pH}$ & 6.70 \\
Organic matter (\%) & 50.2 \\
$\mathrm{~N}(\%)$ & 1.12 \\
$\mathrm{P}(\%)$ & 0.09 \\
$\mathrm{~K}(\%)$ & 0.51 \\
\hline
\end{tabular}

The applications of mineral fertilizer, the different leonardite doses or both to the soils seemed to vary the sand content (3\% to $6 \%$ ), and clay content, ( $1 \%$ to $4 \%$ ), whereas it increased the silt content (5\% to $8 \%$ ). The soil moisture content also increased $11 \%$ to $40 \%$ more with the applications of mineral fertilizer, the different leonardite doses or both (Table 3).

\section{The Characters and Yields of Taşköprü Garlic with} the Different Treatments

The effects of mineral fertilizer, the different leonardite doses and both applications on the different characters and yield of Taşköprü garlic are shown in Table 4. All type of applications significantly $(\mathrm{P}<0.001)$ varied the characteristics and the yields of Taşköprü garlic. However, the application of both the different leonardite doses and the mineral fertilizers together clearly showed the highest values compared to the control and the other treatments (Table 4). For example, compared to the control plots $(25.3 \pm 4.69 \mathrm{~g})$ the bulb weight gradually increased with the applications of mineral fertilizer $(27.8 \pm 3.00 \mathrm{~g})$ and the 
different dose leonartite (ranged from $30.8 \pm 3.80 \mathrm{~g}$ to $35.7 \pm 4.33 \mathrm{~g}$ ), and it had the highest values with the mixture of both mineral fertilizers and the different leonardite dose applications (ranged from $36.0 \pm 2.42 \mathrm{~g}$ to $41.8 \pm 2.65 \mathrm{~g}$ ). Similar variations in the bulb length $(\mathrm{mm})$, equatorial diameter $(\mathrm{mm})$, weight of cloves $(\mathrm{g})$, width of cloves $(\mathrm{mm})$ and length of cloves $(\mathrm{g})$ were also found with the different fertilizer treatments (Table 4). As seen for all the other garlic characters, the plots with highest doses $(9.7$ tones ha-1) $\mathrm{Leo}_{3} \mathrm{MF}$ application had the highest bulb yield (g per plot) and bulb yield $\left(\mathrm{kg} \mathrm{da}^{-1}\right)(3867 \pm 25.0 \mathrm{~g}$ per plot and $1343 \pm 86.9 \mathrm{~kg} \mathrm{da}^{-1}$ respectively) compared to the control ( $2167 \pm 39.5 \mathrm{~g}$ per plot and $753 \pm 130.7 \mathrm{~kg} \mathrm{da}^{-1}$ respectively), the mineral fertilizer $(2487 \pm 28.5 \mathrm{~g}$ per plot and $864 \pm 99.0$ $\mathrm{kg} \mathrm{da}^{-1}$ respectively) and the different dose leonardites (mean $3052 \mathrm{~g}$ per plot and $1060 \mathrm{~kg} \mathrm{da}^{-1}$ ).

Percent N, P and K in the garlic leaves after harvesting also showed significant variations with the applications of mineral fertilizers, the leonardite and the mixtures of both (Table 5). Mean nitrogen, phosphorus and potassium concentrations in the leaves of garlic were 1.3-, 1.2- and 1.4-fold higher in the soils with the mineral fertilizer respectively, 1.4, 1.5 and 1.7 fold with the different dose leonardites respectively, and 1.4, 1.8 and 2.4 fold with the mixture of both the mineral fertilizer and the different dose leonardites respectively compared to the control plots. The ratio of N:P in the garlic leaves did not vary between the different fertilizer treatments. However, the ratio of $\mathrm{N}: \mathrm{K}$ in the garlic leaves showed the highest ratio from the control plots (2.39), whereas it showed the lowest ratio from the $\mathrm{Leo}_{3} \mathrm{MF}$ application plots (1.68).

To estimate the degree of relationship between the soil properties and the garlic yields, a correlation matrix was created using the soil properties and yield data from all different fertilizer treatments (Table 6). Of the soil properties, the garlic yield was strongly positively correlated with the soil $\mathrm{N}$ concentration $(\mathrm{r}=0.891)$, the soil $\mathrm{K}$ concentration $(\mathrm{r}=0.878)$ and the soil organic carbon $(\mathrm{r}=0.827)$. This indicates that among the soil properties measured, the higher soil $\mathrm{N}$ concentrations due to the applications of the leonardite alone or the mixture of leonardite with the mineral fertilizer were having the greatest effect on the garlic yields as shown in Figure 3.

Table 3. Soil physical and chemical properties of experimental sites after harvesting

\begin{tabular}{|c|c|c|c|c|c|c|c|c|}
\hline \multirow{2}{*}{ Soil properties } & \multicolumn{8}{|c|}{ Treatments } \\
\hline & Cont. & MF & $\mathrm{Leo}_{1}$ & $\mathrm{LeO}_{2}$ & $\mathrm{LeO}_{3}$ & & $\mathrm{LeO}_{2} \mathrm{MF}$ & $\mathrm{MF}$ \\
\hline $\mathrm{pH}\left(\mathrm{H}_{2} \mathrm{O}\right)$ & $7.75^{\mathrm{d}} \pm 0.36$ & $7.21^{\mathrm{c}} \pm 0.05$ & $6.21^{\mathrm{ab}} \pm 0.06$ & $6.18^{\mathrm{ab}} \pm 0.04$ & $6.31^{\mathrm{b}_{ \pm}}$ & 6.14 & $6,15^{\mathrm{a}} \pm 0.04$ & 6,19 \\
\hline $\mathrm{C}(\%)$ & $17^{\mathrm{a}} \pm 0.13$ & $1.88^{\mathrm{b}} \pm 0.48$ & & $2.20^{\mathrm{cd}} \pm 0.23$ & $2.42^{\mathrm{de}_{ \pm}} \pm 0.27$ & $2.42^{\mathrm{de}} \pm 0.19$ & $2.52 \mathrm{e} \pm 0.14$ & .13 \\
\hline $\mathrm{N}(\%)$ & $23^{\mathrm{a}} \pm 0.02$ & $0.26^{\mathrm{a}} \pm 0.01$ & $0.44^{\mathrm{b}} \pm 0.01$ & $0.48^{b} \pm 0.03$ & $0.55^{\mathrm{c}} \pm 0.03$ & $0.64^{\mathrm{c}} \pm 0.01$ & $0.77^{\mathrm{d}} \pm 0.02$ & $=0.03$ \\
\hline & $6^{\mathrm{a}} \pm 3.29$ & $37.6^{\mathrm{a}} \pm 8.65$ & $50.3^{\mathrm{b}} \pm 4.07$ & $55.9^{\mathrm{cd}} \pm 5.73$ & & $61.5^{\mathrm{cd}} \pm 4.85$ & $64.0^{\mathrm{d}} \pm 3.46$ & \\
\hline $\mathrm{TN}_{\text {stock }}$ & $5.75^{\mathrm{a}} \pm 0.39$ & $6.72^{\mathrm{a}} \pm 0.47$ & $11.1^{\mathrm{b}} \pm 0.64$ & $12.2^{\mathrm{b}} \pm 0.38$ & $13.9^{\mathrm{b}} \pm 0.62$ & $16.3^{\mathrm{c}} \pm 0.61$ & 16.6 & 19.9 \\
\hline & $9.3^{\mathrm{a}} \pm 9.3$ & $10.5^{\mathrm{ab}} \pm 1.43$ & $11.1^{\mathrm{b}} \pm 0.50$ & $11.4^{\mathrm{bc}} \pm 0.81$ & $11.8^{\mathrm{bc}} \pm 1.35$ & $12.3^{\mathrm{cd}} \pm 0.39$ & $13.4^{\mathrm{d}} \pm 1.83$ & 14.9 \\
\hline $\mathrm{K}(\mathrm{m}$ & $107^{\mathrm{a}} \pm 15.1$ & $133^{b} \pm 27.4$ & $177^{\mathrm{c}} \pm 4.15$ & $185^{\mathrm{c}} \pm 11.6$ & $227^{\mathrm{d}} \pm 22.7$ & $235^{\mathrm{de}_{ \pm}} \pm 9.42$ & 246 & 9.9 \\
\hline & $70^{\mathrm{a}} \pm 1.8$ & $76^{\mathrm{c}} \pm 1.1$ & $76^{\mathrm{c}} \pm 1.2$ & $73^{\mathrm{b}} \pm 1.5$ & $73^{\mathrm{b}} \pm 1.3$ & & & \\
\hline & $16^{\mathrm{d}} \pm 0.72$ & $10^{\mathrm{b}} \pm 0.70$ & & $11^{\mathrm{c}} \pm 0.65$ & $9^{b} \pm 1$ & & & $10^{\mathrm{b}}$ \\
\hline Clay & $14^{\mathrm{a}} \pm 2$ & $14^{\mathrm{ab}} \pm 1.3$ & $15^{\mathrm{ab}} \pm 1.5$ & $16^{\mathrm{bc}} \pm 1.7$ & $18^{\mathrm{c}} \pm($ & $16^{\mathrm{ab}} \pm 0.7$ & $17^{b c} \pm 3.3$ & \pm 1.3 \\
\hline Soil moisture $(\%)$ & $54^{\mathrm{a}} \pm 3.92$ & $72^{\mathrm{cd}} \pm 1.98$ & $60^{b} \pm 3.62$ & $62^{b} \pm 2.14$ & $71^{c} \pm 9.55$ & $71^{c} \pm 2.07$ & $76^{\mathrm{d}} \pm 2.78$ & $76^{\mathrm{d}} \pm 3.27$ \\
\hline
\end{tabular}

Means with different alphabets in line indicate significant difference between treatments by Duncan's test at $\mathrm{P}<0.001, \mathrm{n}=8$.

Table 4. Mean performance of different characters and yield of Taşköprü garlic with the different treatments

\begin{tabular}{|c|c|c|c|c|c|}
\hline Treatment & Weight of bulb (g) & Length of bulb (mm) & \multicolumn{2}{|c|}{ Equatorial diameter (mm) } & Number of cloves/bulb \\
\hline Cont. & $25.3^{\mathrm{a}} \pm 4.69$ & $37.8^{\mathrm{a}} \pm 3.48$ & & $2^{\mathrm{a}} \pm 3.58$ & $13.0^{\mathrm{a}} \pm 2.69$ \\
\hline $\mathrm{MF}$ & $27.8^{\mathrm{b}} \pm 3.00$ & $40.1^{\mathrm{b}} \pm 3.53$ & & $8^{b} \pm 3.35$ & $13.9^{\mathrm{a}} \pm 1.50$ \\
\hline $\mathrm{Leo}_{1}$ & $30.8^{\mathrm{c}} \pm 3.80$ & $43.0^{c} \pm 2.81$ & & $3^{c} \pm 3.22$ & $15.7^{\mathrm{b}} \pm 1.67$ \\
\hline $\mathrm{LeO}_{2}$ & $32.4^{\mathrm{c}} \pm 3.93$ & $44.5^{\mathrm{cd}} \pm 1.99$ & & $2^{\mathrm{cd}} \pm 2.80$ & $17.1^{\mathrm{c}} \pm 2.01$ \\
\hline $\mathrm{LeO}_{3}$ & $35.7^{\mathrm{d}} \pm 4.33$ & $45.1^{\mathrm{d}} \pm 3.68$ & & $9^{c d} \pm 3.54$ & $18.7^{\mathrm{d}} \pm 2.05$ \\
\hline $\mathrm{Leo}_{1} \mathrm{MF}$ & $36.0^{\mathrm{d}} \pm 2.42$ & $46.2^{\mathrm{d}} \pm 2.95$ & & $4^{\mathrm{cd}} \pm 2.70$ & $19.3^{\mathrm{d}} \pm 1.66$ \\
\hline $\mathrm{LeO}_{2} \mathrm{MF}$ & $39.0^{\mathrm{e}} \pm 1.51$ & $48.3^{\mathrm{e}} \pm 3.25$ & & $7^{\mathrm{d}} \pm 1.48$ & $20.5^{\mathrm{e}} \pm 1.24$ \\
\hline $\mathrm{LeO}_{3} \mathrm{MF}$ & $41.8^{\mathrm{f}} \pm 2.65$ & $49.1^{\mathrm{e}} \pm 2.18$ & & $5^{\mathrm{e}} \pm 2.64$ & $21.0^{\mathrm{e}} \pm 1.41$ \\
\hline Treatment & $\begin{array}{l}\text { Weight of cloves } \\
(\mathrm{g})\end{array}$ & $\begin{array}{l}\text { Width of cloves } \\
(\mathrm{mm})\end{array}$ & $\begin{array}{l}\text { Length of cloves } \\
(\mathrm{mm})\end{array}$ & $\begin{array}{l}\text { Bulb yield/plant per } \\
\text { plot }(\mathrm{g})\end{array}$ & $\begin{array}{c}\text { Bulb yield } \\
\left(\mathrm{kg} \mathrm{da}^{-1}\right)\end{array}$ \\
\hline Cont. & $2.08^{\mathrm{a}} \pm 0.76$ & $8.77^{\mathrm{a}} \pm 2.66$ & $23.4^{\mathrm{a}} \pm 2.71$ & $2167^{a} \pm 39.5$ & $753^{a} \pm 130.7$ \\
\hline $\mathrm{MF}$ & $2.36^{\mathrm{b}} \pm 0.24$ & $9.82^{\mathrm{b}} \pm 1.23$ & $27.8^{\mathrm{b}} \pm 3.25$ & $2487^{b} \pm 28.5$ & $864^{\mathrm{b}} \pm 99.0$ \\
\hline $\mathrm{Leo}_{1}$ & $2.77^{\mathrm{c}} \pm 0.54$ & $16.0^{\mathrm{bc}} \pm 2.52$ & $29.1^{\mathrm{bc}} \pm 6.28$ & $2860^{c} \pm 35.0$ & $993^{c} \pm 122$ \\
\hline $\mathrm{LeO}_{2}$ & $2.95^{\mathrm{cd}} \pm 0.56$ & $18.3^{\mathrm{cd}} \pm 2.36$ & $30.5^{\mathrm{cd}} \pm 3.28$ & $2993^{c} \pm 37.9$ & $1039^{c} \pm 132$ \\
\hline $\mathrm{LeO}_{3}$ & $3.07^{\mathrm{cde}} \pm 0.48$ & $19.8^{\mathrm{cd}} \pm 1.95$ & $31.9^{\mathrm{de}} \pm 3.38$ & $3304^{\mathrm{d}} \pm 39.9$ & $1147^{\mathrm{d}} \pm 139$ \\
\hline $\mathrm{Leo}_{1} \mathrm{MF}$ & $3.14^{\mathrm{de}} \pm 0.46$ & $20.4^{\mathrm{d}} \pm 1.82$ & $32.5^{\mathrm{de}} \pm 3.17$ & $3334^{\mathrm{d}} \pm 23.2$ & $1157^{\mathrm{d}} \pm 80.4$ \\
\hline $\mathrm{LeO}_{2} \mathrm{MF}$ & $3.30^{\mathrm{e}} \pm 0.30$ & $21.0^{\mathrm{d}} \pm 1.37$ & $33.3^{\mathrm{e}} \pm 2.33$ & $3612^{\mathrm{e}} \pm 15.9$ & $1254^{\mathrm{e}} \pm 55.1$ \\
\hline $\mathrm{Leo}_{3} \mathrm{MF}$ & $3.59^{\mathrm{f}} \pm 0.30$ & $22.3^{\mathrm{d}} \pm 2.35$ & $34.1^{\mathrm{e}} \pm 2.30$ & $3867^{f} \pm 25.0$ & $1343^{f} \pm 86.9$ \\
\hline
\end{tabular}

Means with different alphabets in column indicate significant difference between treatments by Duncan's test at $\mathrm{P}<0.001, \mathrm{n}=23$. 
Table 5. Percent N, P and $\mathrm{K}$ in garlic leaves after harvesting

\begin{tabular}{l|ccccc}
\hline \multicolumn{1}{c|}{ Treatment } & $\mathrm{N}(\%)$ & $\mathrm{P} / \%$ & $\mathrm{~K}(\%)$ & $\mathrm{N}: \mathrm{P}$ & $\mathrm{N}: \mathrm{K}$ \\
\hline Cont. & $5.12^{\mathrm{a}} \pm 1.21$ & $0.60^{\mathrm{a}} \pm 0.13$ & $2.14^{\mathrm{a}} \pm 0.11$ & 8.53 & 2.39 \\
$\mathrm{MF}$ & $6.26^{\mathrm{b}} \pm 0.59$ & $0.72^{\mathrm{b}} \pm 0.14$ & $3.02^{\mathrm{b}} \pm 0.16$ & 8.69 & 2.07 \\
$\mathrm{Leo}_{1}$ & $6.76^{\mathrm{b}} \pm 1.32$ & $0.78^{\mathrm{bc}} \pm 0.11$ & $2.89^{\mathrm{b}} \pm 0.32$ & 8.66 & 2.34 \\
$\mathrm{Leo}_{2}$ & $7.23^{\mathrm{cb}} \pm 1.02$ & $0.82^{\mathrm{c}} \pm 0.12$ & $3.23^{\mathrm{b}} \pm 0.09$ & 8.82 & 2.24 \\
$\mathrm{Leo}_{3}$ & $7.59^{\mathrm{c}} \pm 0.99$ & $0.89^{\mathrm{c}} \pm 0.09$ & $3.89^{\mathrm{cd}} \pm 0.22$ & 8.53 & 1.95 \\
$\mathrm{Leo}_{1} \mathrm{MF}$ & $7.90^{\mathrm{cd}} \pm 1.11$ & $0.91^{\mathrm{cd}} \pm 0.08$ & $4.21^{\mathrm{d}} \pm 0.11$ & 8.68 & 1.88 \\
$\mathrm{Leo}_{2} \mathrm{MF}$ & $8.16^{\mathrm{d}} \pm 0.89$ & $0.94^{\mathrm{d}} \pm 0.11$ & $4.56^{\mathrm{d}} \pm 0.07$ & 8.68 & 1.79 \\
$\mathrm{Leo}_{3} \mathrm{MF}$ & $8.44^{\mathrm{d}} \pm 1.23$ & $0.99^{\mathrm{d}} \pm 0.13$ & $5.03^{\mathrm{e}} \pm 0.21$ & 8.52 & 1.68 \\
\hline
\end{tabular}

Means with different alphabets in column indicate significant difference between the treatments by Duncan's test at $\mathrm{P}<0.05, \mathrm{n}=5$.

Table 6. Pearson correlation coefficients between the garlic yields and the soil properties

\begin{tabular}{|c|c|c|c|c|c|c|c|c|c|c|}
\hline Variables & $\begin{array}{l}\text { Garlic } \\
\text { Yields }\end{array}$ & $\mathrm{pH}$ & SOC & $\mathrm{P}$ & $\mathrm{K}$ & Sand & Silt & Clay & $\begin{array}{c}\text { Soil } \\
\text { moisture }\end{array}$ & $\mathrm{N}$ \\
\hline $\begin{array}{l}\text { Garlic } \\
\text { Yields }\end{array}$ & - & & & & & & & & & \\
\hline $\mathrm{pH}$ & $-0.711^{* *}$ & - & & & & & & & & \\
\hline SOC & $0.827^{* *}$ & $-0.724^{* *}$ & - & & & & & & & \\
\hline $\mathrm{P}$ & $0.700^{* *}$ & $-524^{* *}$ & $0.729^{* *}$ & - & & & & & & \\
\hline $\mathrm{K}$ & $0.878^{* *}$ & $-0.777^{* *}$ & $0.886^{* *}$ & $0.765^{* *}$ & - & & & & & \\
\hline Sand & $0.323^{* *}$ & $-0.435^{* *}$ & $0.388^{* *}$ & $0.278^{*}$ & $0.314^{*}$ & - & & & & \\
\hline Silt & $-0.545^{* *}$ & $0.679^{* *}$ & $0.616^{* *}$ & $-0.388^{* *}$ & $-0.531^{* *}$ & $0.622^{* *}$ & - & & & \\
\hline Clay & $0.264^{*}$ & -0.316 & $0.277^{*}$ & 0.125 & $0.262^{*}$ & $-0.386^{* *}$ & $-0.472^{* *}$ & - & & \\
\hline Moisture & $0.631^{* *}$ & $-0.431^{* *}$ & $0.714^{* *}$ & $0.494^{* *}$ & $0.628^{* *}$ & $0.406^{* *}$ & $-0.594^{* *}$ & $0.246^{*}$ & - & \\
\hline $\mathrm{N}$ & $0.891^{* *}$ & $-0.784^{* *}$ & $0.817^{* *}$ & $0.749^{* *}$ & $0.933^{* *}$ & $0.300^{*}$ & $-0.539^{* *}$ & $0.277^{*}$ & $0.608^{* *}$ & - \\
\hline
\end{tabular}

"Correlation is significant at the 0.05 level (two-tailed), ${ }^{* *}$ Correlation is significant at the 0.01 level (two-tailed).

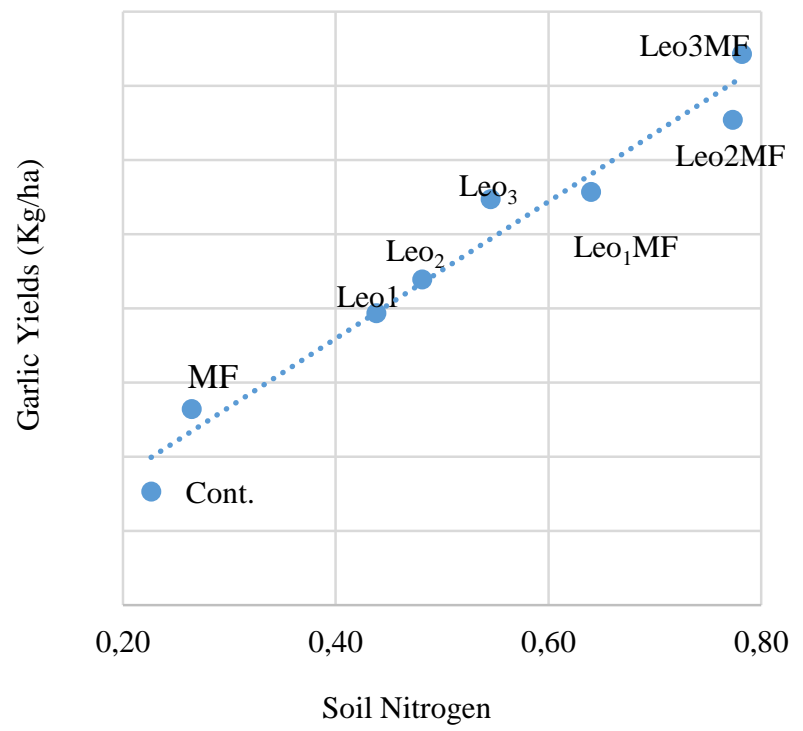

Figure 3. The garlic yields ( $\mathrm{Kg} / \mathrm{ha})$ versus the soil $\mathrm{N}$ contents from the control, the applications of the mineral fertilizer, the different dose leonardites and the mixture of both the leonardite and the mineral fertilizer.

\section{Discussion}

\section{Soil Characteristics of the Experimental Plots}

It was clearly seen from the results of this study that the application of the different leonardite doses and mineral fertilizers (NPK fertilizer) alone positively influenced soil fertility (chemically and physically) of the Taşköprü garlic. On the other hand, the application of leonardite with the mineral fertilizer together had a significant positive effect on the soil $\mathrm{pH}$, soil moisture, soil organic $\mathrm{C}$ and total $\mathrm{N}$ contents, $\mathrm{P}$ and $\mathrm{K}$ concentrations as well as the $\mathrm{SOC}_{\text {stock }}$ and $\mathrm{TN}_{\text {stock }}$ compared to the control and the other applications alone (Table 3). It seems from the literature that there has been a few report on the application of leonardite for soil and crop yield improvement. However, there are several reports on pure humic acid application on crop yield. In those reports, many researchers have stated that using humic substances produced from leonardite as soil amendments can be useful substitutes for mineral fertilization in agriculture (Pascual et al., 1997; Hernandez et al., 2014). Significant impacts of humic substances on soil structure and plant growth are also reported in the literatures (El-Razek et al., 2012; Ihsanullah and Bakhashwain, 2013). They have explained that humic acids can directly affect physical, chemical and biological conditions of soil and also indirectly improve metabolic activity in plant growth (Kumar et al, 2013).

Some researchers have reported that the humic acids produced from leanordite reduce soil $\mathrm{pH}$ around roots and help converting unavailable nutrients to plant accessible forms (Vaughan and Donald, 1976; Chen and Aviad, 1990; Ali and Mindari, 2016). In our study, the soil $\mathrm{pH}$ was initially slightly basic (7.60). After the experiments, it was found that the use of mineral fertilizer slightly decreased the soil $\mathrm{pH}$ by 0.55 unit in comparison to the control (7.75). There was no statistically significant difference among the different leonardite doses either alone or with the mineral fertilizers for the soil $\mathrm{pH}$, but it was seen that the use of leonardite either alone or with the mineral fertilizers significantly decreased soil $\mathrm{pH}$ by $1.44-1.61$ units compared with the control soil (Table 3). Similar to the out results, soil $\mathrm{pH}$ decrease with the use of both mineral 
fertilizers and humic substance was shown by Karcauskiene et al. (2019). In their study, soil pH of the fertilized soil was by $0.31-0.41$ units lower than the control (unfertilized) soil. On the other hand, they noted that mineral fertilizers initially resulted in the fastest soil acidification, while they noted soil $\mathrm{pH}$ decrease after 3 years' time. Compared to their study, in our study, we found annually much higher soil $\mathrm{pH}$ decrease with the use of leonardite either alone or with the mineral fertilizers, and only slightly decrease with the mineral fertilizers. This $\mathrm{pH}$ range appeared to favor nutrient uptake by Taşköprü garlic since the ideal soil reaction for garlic cultivation is desired to be between 6-7 (Akça et al., 2017).

Without any doubt, the most important component of a fertile soil is available water. The stored water in the top soil provides an environment for nutrients required by soil organisms and plant roots. Many researchers have shown that the most important ability of the humic substances is to keep the water in the soil and to provide plants the opportunity to develop better (Suganya and Sivasamy, 2006; Selim et al., 2009; Hassanpanah and Khodadadi, 2009; Olk et al., 2018). Similar to their findings, we also found that percent soil moisture increased $11 \%$ to $40 \%$ with the application of leonardite alone or with the mineral fertilizer together (Table 3).

In our study, there was a significant effect of leonardite either alone or with the mineral fertilizers on the SOC and TN in the soil of Taşköprü garlic (Table 3). The SOC contents in the fertilized treatments varied from $1.88 \%$ (with mineral fertilizer) to $3.10 \%$ ( $\mathrm{Leo}_{3} \mathrm{MF}$ ) compared to the control soil (1.17\%), while the TN contents varied from $0.26 \%$ (with mineral fertilizer) to $0.78 \%$ ( $\mathrm{Leo}_{3} \mathrm{MF}$ ) compared to the control soil $(0.23 \%)$. Other studies have also shown that the use of leonardite as soil amendments with the other organic or inorganic fertilizers can improve soil nitrogen and organic carbon much better (Galloway et al., 2004; Hobbie 2008; Jiang et al., 2010; Powlson et al., 2012). Moreno et al. (2017) found that the use of leonardite mixed with zeolite increased the level of inorganic $\mathrm{N}$ forms (nitrate and ammonium) in soil. Akinremi et al. (2000) found an increase in $\mathrm{N}$ content of canola with increasing leonardite applications. An increases in soil organic $\mathrm{C}$ content due to the leonardite applications was also reported in other studies (Leita et al., 1999; Soler-Rovira et al., 2010; Ondoño et al., 2016; Moreno et al., 2017), and this in turn enhanced soil organic C stocks (Smith, 2004; Diacono and Montemurro, 2010; Bhattacharya et al., 2016). The data in this present study also supported the previous findings, with improving the soil organic $\mathrm{C}$ stocks due to the application of leonardite either alone or with the mineral fertilizers (Table 3). The application of different dose leonardites stored nearly 2 times more SOC in the soil, while the applications of both mineral fertilizers and the different leonardite doses stored 2.7 times more SOC in the soil than the control soil. In addition, our results also showed that the application of different leonardites doses stored 2.4 times more TN in the soil, while the applications of both mineral fertilizers and the different dose leonardites stored 3.5 times more $\mathrm{TN}$ in the soil than the control soil.

It is well documented previously that humic substances can be a reservoir for nitrogen and phosphorus (Qian et al., 2015). The results of this study also indicated that the sandy loam soil of Taşköprü garlic treated with the leonardite alone or with the mineral fertilizers accumulated 2.5-3.5 times more nitrogen, 1.3 - 1.6 times more $\mathrm{P}$ and 2.1 - 2.7 times more $\mathrm{K}$ than traditionally mineral fertilized soil. A good correlation between the addition of leonardite and an increase in soil organic matter and $\mathrm{P}$ was also shown by a number of authors (Duplessis and Mackenzie, 1983; Turgay et al., 2004; Ece et al., 2007). It is well known that $P$ is very important for plant development and growth. The root development can be inhibited by lower phosphates. Wang et al. (2007) reported that humic acids application in an alkaline soils solubilized phosphorus from phosphates and this slowly contributed to the soil's available phosphorus budget. For soil K content, Duplessis and Mackenzie (1983) reported an increase in soil $\mathrm{K}$ level with the leonardite, while Ece et al. (2004) showed a decrease in soil K level with the leonardite application. They attributed this decrease to $\mathrm{K}$ uptake by plants during the growing time. Sanli et al. (2013) have also stated that leonardite can increase available nitrogen, potassium and phosphorus availability in soil, which could be in turn taken up by plants.

The Characters and Yields of Taşköprü Garlic with the Different treatments

The results of this study have indicated that the application of the different leonardite doses alone or with the mineral fertilizers can significantly improve some characters of bulbs (weight, length and equatorial diameter), cloves (number, weight and width) and yields of Taşköprü garlic (Table 4). According to the report by Turkish Agriculture Engineering Chamber, in 2018, the average yield per dry garlic was $798 \mathrm{~kg} \mathrm{da}^{-1}$ (average $882 \mathrm{~kg} \mathrm{da}^{-1}$ in Turkey) (ZMO, 2020). In this present study, the application of leonardite either alone or with the mineral fertilizers improved the dry garlic yields of Taşköprü garlic ranged from $993 \mathrm{~kg} \mathrm{da}^{-1}$ to $1343 \mathrm{~kg} \mathrm{da}^{-1}$ (Table 4). The improvements of all those characters and yields of Taşköprü garlic could be attributed to (1) the positive effects of leonardite on the physical and chemical properties of soil (Ali and Mindari, 2016; Karcauskiene et al., 2019), (2) high available water holding and high adsorption capacities (Suganya and Sivasamy, 2006; Selim et al., 2009), and (3) improvement of nutrient use efficiency by increasing the availability and uptake of macro and micro plant minerals (Akinremi et al., 2000; Qian et al., 2016). A better plant growth due to optimal nutrient availability and soil moisture has been reported by many authors (Mahmoud and Hafez, 2010). A significant increase in soil organic matter and plant growth of onion due to humic acid applications was reported by Erik et al. (2000) and Sajid et al. (2012). A study by Akinremi et al. (2000) showed for canola that leonardite application facilitated nutrient uptake. They also reported that the dry matter of canola increased linearly with the leonardite application at the rates $10,20,60$ and $200 \mathrm{~g}$ to $3 \mathrm{~kg}$ of the soil. Yield increase with the leonardite or humic substances application were also found for cucumber, maize, wheat, cabbage and potato (El-Shabrawy et al., 2010; Ayuso et al., 1996; Delfine et al., 2005; Syabryai et al., 1965; Hopkins and Stark, 2003 respectively). Saha et al. (2014) concluded that the combine application of humic acid and manure considerably influenced rice grain yield. Seyedbagheri (2010) found that tuber yield significantly increased from $11.4 \%$ to $22.3 \%$ with increasing leonardite doses. In our 
study, yield increase of Taşköprü garlic ranged from $38 \%$ to $78 \%$ due to the application of leonardite either alone or with the mineral fertilizers compared to the control, while this increase was only $14 \%$ using the mineral fertilizers alone (Table 4).

In this study, all fertilizer treatments also provided higher nitrogen, phosphorus and potassium concentrations in garlic. However, it was noted that the garlic concentration of nitrogen, phosphorus and potassium increased as the level of leonardite applications either alone or with the mineral fertilizers increased (Table 5). The similar results were noted by Yolcu et al. (2011) for ryegrass and by Akinremi et al. (2000) for canola. On the other hand, several other studies also reported that leonardite, humic substances produced from it or other organic fertilizers such as manure or zeolite increased nutrients in many crops (Akinremi et al., 2000; Butler and Muir, 2006; Gevrek et al., 2009). On the contrary, some studies reported that manure application decreased $\mathrm{Mg}$ in oat plants, while $\mathrm{K}$ and $\mathrm{Ca}$ decreased in corn shoots with zeolite application (Ahmed et al., 2010). In addition, studies with manure application showed no effect on the $\mathrm{K}, \mathrm{Mg}$ and Ca content of cereals and common vetch (Yolcu, 2008; Yolcu et al., 2010). These differences were probably due to the plant species or/and to the various soil and climatic conditions of the experimentation sites.

\section{Conclusions}

In conclusion, the results of the present study suggest that the alternative fertilization treatments with the different leonardite doses either alone or with the mineral fertilizers have a significant individual effect on the soil properties, vegetative growth and yield of Taşköprü garlic in comparison to only conventional fertilization of NPK fertilizer.

The pioneer results have indicated that the application of leonardite with the mineral fertilizer can provide sufficient nutrients to the garlic and improve soil quality. Especially, the use of leonardite in Taşköprü garlic on sandy soils could be beneficial. When all the data are considered, the results indicate that leonardite could be used as soil conditioner material in soils with lower organic matter and nutrients in order to increase the quality and yield of Taşköprü garlic. Further studies are also needed to assess the interaction between leonardite and different soil properties. And the effects of humic and fulvic acids produced from leanordite on the performances of different characters and yield production of Taşköprü garlic should be also studied in future.

\section{Acknowledgements}

This study was supported by Kastamonu University with KUBAP-01-2013-64 project number.

\section{References}

Ahmed OH, Sumalatha G, Nik Muhamad AM. 2010. Use of zeolite in maize (Zea mays) cultivation on nitrogen, potassium and phophorus uptake and use efficiency. Inter. J. Physc. Sci. 15: 2393-2401.

Aisha HA, Shafeek M, Mahmoud RA, El-Desuki M. 2014. Effect of various levels of organic fertilizer and humic acid on the growth and roots quality of turnip plants (Brassica rapa). Curr. Sci. Int. 3: 7-14.
Akça H, Taban N, Turan MA, Taban S, Ouedraogo RA, Türkmen N. 2017. Fertility status of garlic cultivated soils in Turkey. J. Soil Sci. Plant Nutr. 5 (2): 93-100.

Akinremi OO, Janzen RL, Lemke RL, Larney FJ. 2000. Response of canola, wheat and green beans to Leonardite additions. Can. J. For. Res. 80, 437-443. doi:10.4141/S99-058.

Ali M, Mindari W. 2016. Effect of humic acid on soil chemical and physical characteristics of embankment. MATEC. Web of Conferences 58, 01028. DOI: 10.1051/matecconf/ 20165801028

Allen SE. 1989. Chemical Analysis of Ecological Materials. Blackwell Scientific Publications, Oxford.

Anonymous 2012. Taşköprü sarimsak paneli, bildiri notları [Taşköprü garlic panel information note]. T.C. Kuzey Anadolu Kalkinma Ajansi, Kastamonu, Türkiye [North Anatolian Development Agency, Kastamonu, Turkey], 132 p. http://www.kuzka.org.tr/paylasim//Sarimsak\%20Kitabi.pdf

Ayuso M, Hernandez T, Garcia C, Pascual J. 1996. Stimulation of barley growth and nutrient absorption by humic substances originating from various organic materials. Bio-source Tech. 57: 251-257.

Bayrakli B, Gül M. 2018. Analysis of marketing structure and problems in garlic production: The case of Kastamonu Province. Sci. Papers Series Manage. Econ. Eng. Agric. Rural Dev. 18 (2): 21-28.

Bhattacharya SS, Kim KH, Das S, Uchimiya M, Jeon BH, Kwon E, Szulejko JE. 2016. A review on the role of organic inputs in maintaining the soil carbon pool of the terrestrial ecosystem. J. Environ. Manage. 167: 214-227.

Butler TJ, Muir JP. 2006. Dairy manure compost improves soil and increases tall wheatgrass yield. Agron. J. 98: 1090-1096.

Chen J. 2006. The Combined Use of Chemical and Organic Fertilizers and/or Biofertilizer for Crop Growth and Soil Fertility. International Workshop on Sustained Management of the Soil-Rhizosphere System for Efficient Crop Production and Fertilizer Use, Bangkok, 1-11.

Chen Y, Aviad T. 1990. Effects of humic substances on plant growth. In: Humic Substances in Soil and Crop Sciences. Amer. J. Soil Sci. 34: 161-186.

Çobanoğlu S, Cilbircioğlu C, Hepkorucu A. 2016. Effects of Three Acaricides on the Germination Rate and Head Weight of Taşköprü Garlic in Turkey. Open Access Library J. 3 (01): 1-7. e2276. http://dx.doi.org/10.4236/oalib.1102276

Diacono M, Montemurro F. 2010. Long-term effects of organic amendments on soil fertility. A review. Agron. Sustain. Dev. 30: 401-422.

Delfine S, Tognetti R, Desiderio E, Alvino A. 2005. Effect of foliar application of $\mathrm{N}$ and humic acids on growth and yield of durum wheat. Agro. Sus. Dev. 25:183-191.

Duplessis GL, Mackenzie AF. 1983. Effects of leonardite applications on phosphorus availability and corn growth. Can. J. Soil Sci. 63: 749-751.

Ece A, Saltali K, Eryigit N. Uysal F. 2007. The effects of leonardite applications on climbing bean (Phaseolus vulgaris L,) yield and some soil properties. J. Agronomy. 6: 480- 483.

El-Razek EA, Abd-Allah ASE, Saleh MMS. 2012. Yield and fruit quality of Florida Prince peach trees as affected by foliar and soil applications of humic acid. J. Appl. Sci. Res. 8 (12): 5724-5729.

El-Shabrawy RA, Ramadan AY, EI-Kady Sh M. 2010. Use of humic acid and some biofertilizers to reduce nitrogen rates on cucumber (Cucumis sativus L.) in relation to vegetative growth, yield and chemical composition. J. Plant Produc. Mansoura Univ. 1(8): 1041-1051.

Erik B, Feibert G, Shock CC. Saundres, L.D., 2000. Evaluation of humic acid and other non-conventional fertilizer additives for onion productivity. Malheur Experiment Station, Oregon State University Ontario.

Erkoc I 2009. Effects of Sulphur and Leonardit on Phosphor Efficiency in Greenhouse Grown Tomato. MSc. Thesis. Department of Horticulture Institute of Natural and Applied Sciences Universty of Cukurova, p: 127. 
FAO 2018. Statistical Yearbook. Food and Agriculture Organization (FAO). http://www.fao.org/faostat/en/\#data/QC

Galloway JN, Dentener FJ, Capone DG, Boyer EW, Howarth RW, Seitzinger SP, Asner GP, Cleveland CC, Green PA, Holland EA, Karl DM, Michaels AF, Porter JH, Townsend AR, Vosmarty CJ. 2004. Nitrogen cycles: past, present, and future. Biogeochem. 70 (2): 153-226. - doi: 10.1007/s10533-004-0370-0

Gevrek MN, Tatar O, Yagmur B, Ozaydin S. 2009. The effects of clinoptilolite application on growth and nutrient ions content in rice grain. Turk. J. Field Crops 14: 79-88.

Gulcur F 1974. Physical and Chemical Analysis Methods of Soil. I. Univ. Forestry Faculty Publications. No: 201, Istanbul

Halil Y, Hayati S, Gullap MK, Anastasios L, Adem G. 2011. Application of cattle manure, zeolite and leonardite improves hay yield and quality of annual ryegrass (Lolium multiflorum Lam.) under semiarid conditions. Aust. J. Crop Sci. 5(8): 926-931.

Hassanpanah D, Khodadadi M. 2009. Evaluation of potassium humate effects on germination, yield and yield components of HPS-II/67 hybrid true potato seeds under in vitro and in vivo conditions. Am. J. Plant Physiol. 4: 52-57.

Henao J, Baanante C. 1999. Estimating rates of nutrient depletion in soils of agricultural lands of Africa. Inter. Fert. Dev. Center (IFDC), Muscle Shoals, Alabama, USA. 76 pp.

Hernandez T, Chocano C, Moreno JL, Garcia C. 2014. Towards a more sustainable fertilization: Combined use of compost and inorganic fertilization for tomato cultivation. Agr. Ecosyst. Environ. 196: 178-184

Hobbie SE. 2008. Nitrogen effects on decomposition: a five-year experiment in eight temperate sites. Ecology 89 (9): 26332644. - doi: 10.1890/07-1119.1

Hopkins B, Stark J. 2003. Humic acid effects on potato response to phosphorus. Idaho Potato Conference January 22-23, p.: 87-92.

Jiang C, Yu G, Fang H, Cao G, Li Y. 2010. Shortterm effect of increasing nitrogen deposition on $\mathrm{CO}_{2}, \mathrm{CH}_{4}$ and $\mathrm{N}_{2} \mathrm{O}$ fluxes in an alpine meadow on the Qinghai-Tibetan Plateau, China. Atmos. Environ. 44 (24): 2920-2926. doi: 10.1016/j.atmosenv.2010.03.030

Ihsanullah D, Bakhashwain AA. 2013. Effect of humic acid on growth and quality of maize fodder production. Pak. J. Bot. 45: $21-25$.

Ibret BU. 2005, a geographical study on garlic agriculture and Taşköprü Garlic in Turkey (in Turkish). Marmara Coğrafya Dergisi (Marmara Geogr. Rev.), 12: 17-50.

Kalra YP, Maynard DG. 1991. Methods Manual for Forest Soil and Plant Analysis. For. Can., Northwest Reg., North. For. Cent., Edmonton, Alberta. Inf. Rep. NOR-X-319, Canada.

Karčauskienė D, Repšienė R, Ambrazaitienè A, Mockevičienė I, Siaudinis G, Skuodienè R. 2019. A complex assessment of mineral fertilizers with humic substances in an agroecosystem of acid soil. Zemdirbyste-Agric. 106 (4): 307-314.

Kaul MK. 1997. Medicinal Plants of Kashmir and Ladakh: Temperate and Cold Arid Himalaya. Indus Publishing Co., New Delhi, 173 p.

Kumar D, Singh AP, Raha P, Rakshit A, Singh CM, Kishor P. 2013. Potassium humate: a potential soil conditioner and plant growth promoter. Int. J. Agric. Environ. Biotec. 6 (3): 441-446. https://doi.org/10.5958/j.2230-732X.6.3.015

Kumar R, Kumar R, Prakash O. 2005. The Impact of Chemical Fertilizers on our Environment and Ecosystem, In book: Research Trends in Environmental Sciences, Edition: 2nd, Chapter: 5, pp.:69-86.

Lee J, Hopmans JW, Rolston DE, Baer SG, Six J. 2009. Determining soil carbon stock changes: simple bulk density corrections fail. Agric. Ecosyst. Environ. 134 (3): 251256.

Leita L, De Nobili M, Mondini C, Muhlbachova G, Marchiol L, Bragato G, Contin M. 1999. Influence of inorganic and organic fertilization on soil microbial biomass, metabolic quotient and heavy metal bioavailability. Biol. Fert. Soils. 28 371-376.
Mahmoud Asmaa R, Hafez Magda M. 2010. Increasing productivity of potato plants (Solanum tubersoum L.) by using potassium fertilizer and humic acid application. Int. J. Acad. Res. 2: 83-88.

Moreno1 JL, Ondoño1 S, Torres I, Bastida F. 2017. Compost, leonardite, and zeolite impacts on soil microbial community under barley crops. J. Soil Sci. Plant Nutr. 17 (1): 214-230.

Olk DC, Dinnes DL, Scoresb, JR, Callaway CR, Darlington JW. 2018. Humic products in agriculture: potential benefits and research challenges - a review. J Soils Sediments. 18: 28812891. doi: 10.1007/s11368-018-1916-4

Ondoño S, Martinez-Sanchez JJ, Moreno JL. 2016. The composition and depth of green roof substrates affect the growth of Silene vulgaris and Lagurus ovatus species and the $\mathrm{C}$ and $\mathrm{N}$ sequestration under two irrigation conditions. J. Environ. Manage. 166: 330-340.

Paksoy M, Türkmen Ö, Dursun A. 2010. Effects of potassium and humic acid on emergence, growth and nutrient contents of okra (Abelmoschus esculentus L.) seedling under saline soil conditions. Afr. J. Biotechnol. 9: 5343-5346.

Pascual JA, Ayuso M, Hernandez T, Garcia C. 1997. Phytotoxicity and fertilizer value of different organic materials. Agrochimica. 41: 50-62.

Powlson DS, Bhogal A, Chambers BJ, Coleman K, Macdonald AJ. 2012. The potential to increase soil carbon stocks through reduced tillage or organic material additions in England and Wales: a case study. Agric. Ecosyst. Environ. 146, 23-33. https://doi.org/10.1016/j.agee.2011.10.004

Qian S, Ding W, Yang Y, Sun J, Ding Q. 2016. Humic acids derived from leonardite-affected growth and nutrient uptake of corn seedlings. Commun. Soil Sci. Plant Anal. 47 (10): 1275-1282. DOI: 10.1080/00103624.2016.1178767

Saha R, Saieed MAU, Chowdhury MAK, Chowdhury MAH. 2014. Influence of humic acid and poultry manure on nutrient content and their uptake by T. aman rice. J. Bangladesh Agric. Univ. 12 (1): 19-24.

Sajid M, Rab A, Shah ST, Jan I, Haq I, Haleema B, Zamin M, Alam R, Zada H. 2012. Humic acids affect the bulb production of onion cultivars. Afr. J. Microbiol. Res. 6:57695776.

Sanli A, Karadogan T, Tonguc M. 2013. Effects of leonardite applications on yield and some quality parameters of potatoes (Solanum tuberosum L.). Turk. J. Field Crops. 18 (1): 20-26.

Schnitzer MM. 1992. Significance of soil organic matter in soil formation, transport processes in soils and in the formation of soil structure. Humus Budget 206: 63-81.

Selim EM, Mosa AA, El-Ghamry AM. 2009. Evaluation of humic substances fertigation through surface and subsurface drip irrigation systems on potato grown under Egyptian sandy soil conditions. Agr. Water Manage. 96: 1218-1222.

Seyedbagheri Mir-M. 2010. Influence of humic products on soil health and potato production. Potato Res. 53: 341-349.

Shafeek MR, Ali AH, Mahmoud AR, Hafez MM, Rizk FA. 2015. Improving growth and productivity of garlic plants (Allium sativum $\mathrm{L}$.) as affected by the addition of organic manure and humic acid levels in sandy soil conditions. Int. J. Curr. Microbiol. App. Sci. 4: 644-656

Smith P. 2004. Carbon sequestration in croplands: the potential in Europe and the global context. Eur. J. Agron. 20: 229-236.

Soler-Rovira P, Madejon E, Madejon P, Plaza C. 2010. In situ remediation of metal-contaminated soils with organic amendments: Role of humic acids in copper bioavailability. Chemosphere. 79: 844-849.

Suganya S, Sivasamy R. 2006. Moisture retention and cation exchange capacity of sandy soil as influenced by soil additives. J. Appl. Sci. Res. 2: 949-951.

Sugier D, Kolodziej B, Bielinska E. 2013. The effect of leonardite application on Arnica montana L. yielding and chosen chemical properties and enzymatic activity of the soil. J. Geochem. Explor. 129: 76-81. 
Syabryai VT, Reutov VA, Vigdergauz LM. 1965. Preparation of humic fertilizers from brown coal. Geol. Zh. Akad. Nauk Ukr. 25: 39-47.

Taban S. Çikili Y, Kebeci F, Taban N, Sezer SM. 2004. Fertility status and potential nutritional problems of Taşköprü garlic soils. Ankara Univ. Faculty Agric. Sci. J. 10: 297-304

Tan ZX, Lal R, Wiebe KD. 2005. Global Soil Nutrient Depletion and Yield Reduction. J. Sustainable Agric. 26 (1): 123-146. DOI: 10.1300/J064v26n01_10.

Turgay OC, Tamer N, Turkmen C, Karaca A. 2004. Soil microbial biomass for determination of effect of various of gyttja on soil biological characteristics. Proceedings of the 3rd National Fertilizer Congress, October 11-13, 2004, Tokat, Turkey, pp: 827-836.

Vaughan D, MacDonald IR. 1976. Some effects of humic acid on cation uptake by parenchyma tissue. Soil Biol. Biochem. 8: 415-421.
Wang XJ, Wang ZQ, Li SG. 2007. The effect of humic acids on the availability of phosphorus fertilizers in alkaline soils. Soil Use Manage. 11(2): 99-102. https://doi.org/10.1111/j.14752743.1995.tb00504.x

Yolcu H. 2008. The effects of stable manure application on the yield, morpholgical and qualities of the cultivars of barley and wheat as fodder crops. Ondokuz Mayıs Uni Agric. Fac. J. 23: 137-144.

Yolcu H. 2010. Effects of some organic and chemical fertilizers on yield and mophologic properties of common vetch in spring latest frost conditions. Turkey IV. Organic Agric. Symp. 28 June - 1 July 2010. Erzurum.

Yolcu H, Seker H, Gullap MK, Lithourgidis A, Gunes A. 2011. Application of cattle manure, zeolite and leonardite improves hay yield and quality of annual ryegrass (Lolium multiflorum Lam.) under semiarid conditions. Australian J. Crop Science, 5(8): 926-931.

ZMO. 2020. The garlic report in 2019. Access date 2020. http://zmo.org.tr/genel/bizden_detay.php?kod=31850\&tipi= $17 \&$ sube $=0$ 